\title{
Article
}

\section{Sustainable development of socio-cultural capital in the city divided by border}

\author{
Bogusław Dziadzia 1, Łukasz Wróblewski 2,* \\ 1 Department of Cultural Education, University of Silesia in Katowice, 40-007 Katowice, Poland; \\ boguslaw.dziadzia@us.edu.pl \\ 2 Department of Management and Production Engineering, WSB University,41-300 Dąbrowa Górnicza, Poland \\ * Correspondence: lwroblewski@wsb.edu.pl; Tel.: +48-692-344-057
}

\begin{abstract}
The article presents the concept of sustainable development of socio-cultural capital with particular emphasis of the role of cultural institutions as factors influencing their development in a human being. In the article, the concept of social capital and cultural capital have been treated as complementary to each other, which is why they have been identified as a socio-cultural capital. Sustainable development of this capital in many cities of the world meets a number of problems reflected in the quality of life of its residents. In this article, a part of the town is analyzed which, due to political decisions made at the end of the First World War, has been divided for a hundred years into Cieszyn on the Polish side of the border and Czech Cieszyn (Český Těšín). This area is an example of how historical, political, demographic and educational conditions form the basis for the quality of socio-cultural capital. It is also an example of cooperative activities between local government institutions and third sector organizations. Despite many differences between the residents of Cieszyn and Czech Cieszyn, the conducted analysis points to the formation of a sociocultural capital of a combining character, according to how Robert Putnam wrote about such phenomena, without neglecting the diversity of goals and interaction groups.
\end{abstract}

Keywords: sustainable development, socio-cultural capital, city divided by the border, CieszynČeský Těšín

\section{Introduction - Social and cultural capital and responsibility for city development}

Sustainable development of social and cultural capital and its importance for the development of a city is determined by a number of complementary factors. These factors oscillate around the balance between identifying the cultural needs of different social groups and the possibilities of pursuing the articulated goals. The entities responsible for the shape and development of this capital are primarily institutions of local and national culture (in this case, it should be said government). In the development of modern societies, in a system forming the area of cultural subjects, the so-called third sector organisation (often called the NGO or non-governmental organizations) is increasingly important. Therefore, speaking of sustainable development of socio-cultural capital, it is the responsibility for culture (including primarily the cultural offer) which local governments and third sector organizations assume, that is first and foremost understood for the purpose of this study. The issue of the existence of the state border that crosses the city under analysis is in this case an important political and social factor that poses a challenge to the quality of the forms of capital, both cultural and social. The border and attachment to a given nation is not illusory in the area described - despite both sides belonging to the European Community and the Schengen Area. Even if we accept this belonging to the nation as such, which is inherently an imagined political community and as imagined, it is limited and sovereign (Anderson 2006, p. 6), it is a question of this symbolic assignment to the national community that cannot be ignored for these deliberations. This 
community, as Benedict Anderson (2006) pointed out, is imaginary because members of even the smallest nation will never meet the majority of other members, nor will they meet them, or even hear about them. Yet, in the minds of each of them lives the image of their community. Outlining the concept of sustainable development of socio-cultural capital in the indicated example of the city, we indicate how current needs and interests in the domain of culture can be conditioned by various forms of belonging and self-identification. Moreover, as part of the past, they make history the connecting and disintegrating factor.

The area of analysis in this article is the city which, due to political decisions that took place at the end of World War I, has been divided into Cieszyn and Czech Cieszyn (Český Těšín) for 100 years. It is a system of cities which in 2007 entered the so-called Schengen area, and therefore visafree traffic without border controls. However, despite the opening of the borders, in 2018 the sociocultural capital of this area is still intertwined with the past history. What's more, not only the latest history, but also one reaching back hundreds of years (Wróblewski et al. 2018). An important role in its formation was played by both natural migration movements and politics. Particularly, changes in the national composition of the population, which largely affected the Czech side of the city - the formerly predominant population in this area, that declares themselves as Poles, currently constitutes only a few percent of the population. The change in this composition resulted from political motives aimed at marginalizing the previous city hosts (Wróblewski 2014; 2016). No less important were also economic reasons related to the economic development of the city and its surroundings. In the opinion of the authors, these changes in the population structure are of fundamental importance for the formation of social and cultural capital of two cities as a whole. For this capital is developed by people looking at their place of residence from very different perspectives. New inhabitants, brought in the second half of the twentieth century to the city of Czech Cieszyn from the Czech and Slovakian depths, are not - as Simone Weil (2002) would say - rooted in this land, they do not have that foundation that inherently forms the human identity. On the other hand, that part of the inhabitants that can derive their broodline from the times of the late Middle Ages, often nurturing the past of the city, does not see its current needs.

The past and socio-political changes largely determine the forms of activities for the production of social and cultural capital. The Olza River, along which the state border runs, is in the described area a kind of mental barrier that, despite the formal abolition of borders, is nurtured in the hearts of the inhabitants of both banks of the river (Kurowska-Pysz et al. 2018a). Despite the right to cross it freely, the existence of a border has consequences for the self-identification of residents. It is worth noting here that Poland and the Czech Republic are countries at a similar level of development. In terms of competitiveness, both countries in the global ranking on the competitiveness of The Global Competitiveness Report for 2016-2017 (Schwab 2018) are relatively high, because they are already in the top ten. Many values are shared by these countries, among which the family and health are the most valued. Inhabitants of both countries - which is important for building social and cultural capital are characterized by a low level of trust in politics. In view of the numerous similarities that could be pointed here, one area diametrically differentiates both nations. It is an attitude to religion. According to the findings of the Global Index of Religiosity And Atheism, 81\% of Poles consider themselves religious, while from the Czech Republic it is only 20\%. The Czechs, despite their closeness to Poland, in terms of religiosity are closer to countries such as China and Japan, where the highest percentages of declared atheists are found (Global Index Of Religiosity And Atheism 2012). The issue of attitude to religion does not appear in this article by chance as it is one of the aspects that can be related to mutual trust and understanding of the attitudes of the inhabitants of both sides of the border, expressed likes and dislikes. These problems may directly affect the quality and the possibility of social and cultural capital development. Despite the indicated differences, the average Pole, among all the countries of the world, bestows the Czechs with the greatest affection (Relation of Poles to other nations 2013). At the same time, the Poles, in the same rankings, are in the distant positions for the Czechs. It is worth noting, however, that as a national minority (in the city of Czech Cieszyn, Poles constitute a significant minority) Poles for the Czechs are at the top of the classification (Vztah ceské verejnosti k národnostním skupinám zijícím v CR, 2015).

The above mentioned conditions are just some of the problems which in are faced in the everyday practice by those who undertake actions for the cohesion, production and development of socio-cultural capital in the divided city of Cieszyn and Czech Cieszyn. Undertaken efforts often meet 
with incomprehension, they collide with a strong sense of alterity, often with reluctance and with various forms of chauvinism and xenophobism (Kurowska-Pysz et al. 2018b). Reluctance may take the form of a disrespectful attitude towards the residents of the 'other side of the city', verbal jokes or indifference. It can also be acute in social situations, such as in the forms of public dislike of representatives of foreign nationalities in public places. However, the prosaic ignorance of the inhabitants of two cities towards each other is predominant. Hence, the people and institutions involved in culture take on a particular kind of responsibility, where local and national interests are complementary to each other, but also often contradictory. At the same time, though it is ironic, a lot of significant cultural events and institutions, which by definition are meant to connect the two cities, have the word 'border' in their name (their names appear later in the study).

\section{The local community and its diversity}

Pierre Bourdieu (1994, p. 229) in Distinction. And the social Critique of the Judgment of Taste rightly pointed out that 'The mystery of culture has its catechumens, the initiated, sanctified people, a kind of 'discrete elite' separated from ordinary mortals'. The area of our interest, however, largely contradicts this kind of simplification. Certainly, in the divided city of Cieszyn and Czech Cieszyn, there are those with greater and more precise knowledge than other residents as far as the broadly understood culture is concerned. The concept of an elite, however, is in their case an abuse for various reasons. Sustainable development of socio-cultural capital in this case refers to the distribution of the emphasis of responsibility for local culture, which is co-created. And it is created equally by both public cultural institutions and third sector organizations, both directors of cultural institutions and volunteers (often students) initiating and organizing new cultural ventures (Wróblewski 2014; 2015). The socio-cultural capital inspired and produced by them is focused primarily on accessibility, and this excludes elitism. Even those forms of culture that require special competence, by definition in Cieszyn and Czech Cieszyn, are open to every interested citizen. The exception may be only the time when there is an economic barrier, related to e.g. performances of popular stage and screen stars in the city theatre. Tickets for such events, especially for young residents, can be a sum exceeding their financial possibilities. The organizers of cultural life usually have an internalized awareness of their place in the structure of the local community. Cities of the size of Cieszyn (36 thousand inhabitants) and Czech Cieszyn (25 thousand inhabitants) constitute a kind of province. This province, however, is not understood in a pejorative way. One can see a whole range of positives in it, and even associate with it some kind of pride connected with being its inhabitant (Dziadzia 2014), which probably would not have been perceived by class-oriented Pierre Bourdieu.

People involved in social and cultural capital, build a common locality of the two cities not only because of the spatial proximity, but because of the ability to social reproduction (Appadurai 2015, p. 264). Many activities and events are cyclical, and some have many years of tradition. What is quite surprising, the media market and mainly magazines that appear on both sides of the Olza, are not too involved in the creation of a community of two cities, as representatives of local government and the third sector. The Czech-language and Polish-language media primarily focus on the issue of their city side. However, many institutions (not only related to culture) have their websites published in both languages.

The social and cultural capital of the city of Cieszyn and Czech Cieszyn is developing at many different levels (Kurowska-Pysz 2015; Castanho et al. 2016). This applies to both economically significant projects, such as the joint investment 'Garden of two shores' (co-financed from the European Union funds from the European Regional Development Fund) and flagship events, which is exemplified by the city's biggest Three Brothers Festival in terms of turnout. The key to the sustainable development of social and cultural capital, however, is the commitment and joint responsibility for the city of self-government authorities and the citizens involved. The cooperation of the city and poviat authorities with the third sector is currently implemented on many levels. Local government authorities are involved in almost every major event organized by representatives of the third sector. This applies to a number of small initiatives as well as international events that, over the years, have contributed to shaping a positive image of cities (Wróblewski 2017a). These are primarily the events of the Film Review 'Cinema on the Border' (Filmová přehlídka Kino na hranici) or the Theatre Festival 'Without Borders' (borderfestival.eu). The cultural offer of both cities are many 
institutions whose proposals are not limited to recipients on one side of the river, along which the border extends. Despite the small size, the city as a whole has two theatres. On the Polish side, it is the Theatre named after Adam Mickiewicz, on the Czech side it is a theatre with a double, namely Polish and Czech scene. What is particularly interesting is the fact that the Polish scene located in Těšínské Divadle is financed by the Czech marshal's office without subsidies from Polish sources. Two large cultural centres operate in the city as a whole: Cieszyn Culture Centre National House and Kulturní a společenské středisko Střelnice. Important points of culture are the Municipal Library in Cieszyn, the Municipal Library in Czech Cieszyn (Městská knihovna Český Těšín), Reading Room and Literary Café Avion (Č́tárna a kavárna Avion), known internationally and dealing in design Cieszyn Castle, Museum of Cieszyn Silesia, or Cieszyn Historical Library (Książnica Cieszyńska) which has had many unique publications from the last five hundred years. Sustainable development for both cities is also the activity of associations. The most visible are: Association for Regional Development and Cooperation 'Olza', Euroregion Cieszyn Silesia, Polish Cultural and Educational Association, Congress of Poles in the Czech Republic, Association 'Culture on the Border', Association Člověk na hranici (Man on the Border), Polish-Czech-Slovak Solidarity, Association Education Talent Culture. More or less significant initiatives and places in private hands also cannot be overlooked. Such places also enrich cultural capital and work for the image of cities, as well as large local government institutions. These include Literary Café Kornel i Przyjaciele, Tea Room Laja, Klub Dziupla, Blady Dawn Bar (Bledý úsvit), or events like a series of charity concerts called Activate Good. The above set includes actions on the social field, and undertaken by third sector organizations, which is exemplified by the Association for Mutual Assistance Being Together. Significant, and of great significance for the social and cultural capital of the city as a whole, is the fact that numerically non-governmental organizations find their headquarters mainly on the Polish side. In Czech Cieszyn, this type of social involvement was not created. A large number of cultural entities actively involved in Cieszyn and Czech Cieszyn directly generate a rich and diverse artistic offer in terms of culture. The analysis of substantive reports of Cieszyn's local government cultural institutions shows that only the self-government cultural institutions of Cieszyn in 2016 organized over 1,600 cultural events of various nature, in which (as estimated by the organizers of these events) over 265,000 people took part (Table 1).

Table 1. Cultural and educational activity of local cultural institutions in Cieszyn.

\begin{tabular}{|l|l|c|c|c|c|c|c|}
\hline \multirow{2}{*}{ No. } & \multirow{2}{*}{ Cultural Institution } & \multicolumn{2}{|c|}{$\mathbf{2 0 1 4}$} & \multicolumn{2}{|c|}{$\mathbf{2 0 1 5}$} & \multicolumn{2}{c|}{$\mathbf{2 0 1 6}$} \\
\cline { 3 - 8 } & & $\begin{array}{l}\text { Number } \\
\text { of events }\end{array}$ & $\begin{array}{c}\text { Number of } \\
\text { participants }\end{array}$ & $\begin{array}{c}\text { Number } \\
\text { of events }\end{array}$ & $\begin{array}{c}\text { Number of } \\
\text { participants }\end{array}$ & $\begin{array}{c}\text { Number } \\
\text { of events }\end{array}$ & $\begin{array}{c}\text { Number of } \\
\text { participants }\end{array}$ \\
\hline 1 & $\begin{array}{l}\text { Cieszyn Cultural Centre } \\
\text { 'National House" }\end{array}$ & 437 & 165230 & 373 & 152000 & 400 & 145704 \\
\hline 2 & $\begin{array}{l}\text { Theatre named after } \\
\text { Adam Mickiewicz }\end{array}$ & 128 & 63554 & 129 & 61937 & 127 & 65560 \\
\hline 3 & Cieszyn Castle & $\begin{array}{c}\text { lack of } \\
\text { data }\end{array}$ & lack of data & $\begin{array}{c}\text { lack of } \\
\text { data }\end{array}$ & lack of data & 128 & 22651 \\
\hline 4 & $\begin{array}{l}\text { Cieszyn Song and Dance } \\
\text { Ensemble named after im. } \\
\text { Janina Marcinkowa }\end{array}$ & 62 & lack of data & 72 & lack of data & 47 & lack of data \\
\hline 5 & $\begin{array}{l}\text { Cieszyn Historical } \\
\text { Library }\end{array}$ & 84 & 2567 & 93 & 5037 & 138 & 5584 \\
\hline 6 & $\begin{array}{l}\text { Municipal Library } \\
\text { in Cieszyn }\end{array}$ & 342 & 13663 & 684 & 25602 & 819 & 26027 \\
\hline Total & & $\mathbf{1 0 5 3}$ & $\mathbf{2 4 5 0 1 4}$ & $\mathbf{1 3 5 1}$ & $\mathbf{2 4 4 5 7 6}$ & $\mathbf{1 6 5 9}$ & $\mathbf{2 6 5 5 2 6}$ \\
\hline
\end{tabular}

Data source: Collected by this research.

In order to get a more complete idea of the richness of social and cultural capital of Cieszyn and Czeski Cieszyn, the cultural offer of private cultural entities and non-governmental organizations operating in the sphere of culture should also be taken into account, as well as the offer of cultural entities located on the other side of the border in Czech Cieszyn. Unfortunately, the lack of a uniform formula of the substantive report for local cultural institutions from Czech Cieszyn made it 
impossible to precisely determine the number of cultural events organized in both cities. Analysing descriptive reports and websites of cultural institutions in Czech Cieszyn, it can be noticed that high activity in organizing various types of cultural events, and thus a significant contribution to the development of social and cultural capital, are brought by cultural institutions such as:

- Městká knihovna, which in 2017 organized 751 cultural events and 310 training events,

- KaSS Střelnice, this institution organized in 2017 as many as 870 cultural and social events, in which the organizers estimated more than 58 thousand people attended,

- Těšínské divadlo, which in 2017 performed a total of 533 performances, of which 238 on the own stage in Czech Cieszyn, 79 performances abroad (Poland, Slovakia, Ukraine) and 216 performances in the Czech Republic outside the home stage.

The rich cultural offer of Cieszyn and Czech Cieszyn is a very important resource thanks to which, using the synergy effect, the development of social and cultural capital divided by the city's border can be stimulated (Wróblewski 2016). A significant number, high quality and high dynamics of Polish-Czech cross-border contacts in the field of culture indicate that this area of human activity may in the future be even more integrated, which is supported by, among others:

- an important place of culture in strategic documents of both cities, Cieszyn poviat, Euroregion Cieszyn Silesia and provinces on both sides of the border (Kurowska-Pysz et al. 2017, pp. 3317-3327),

- a large number of various types of entities: public, commercial, and non-governmental entities involved in culture on both sides of the border (Wróblewski 2017b, pp. 79-92),

- the importance of culture as an element working on other areas important in the socioeconomic development of the whole region (e.g. tourism) (Kurowska-Pysz, p. 230),

- multiplicity and relative durability of bilateral partnerships based on cross-border projects in the field of culture, in particular on projects co-financed by the European Union, which foster the strengthening of cross-border cooperation (Wróblewski et al. 2018, pp. 3131-3141)

There is a deep awareness of the place of residence in Cieszyn. Many involved in the culture and social life of this place, implement the words of the world-renowned sociologist, connected to the Cieszyn region, Jan Szczepański (2013, p. 8), who claimed that '(...) we can only contribute to the original contribution to the society's achievements, how much we can radiate with their own unique individuality. Without reflection on the roots of this individuality for ourselves, we cannot define and we cannot determine ourselves'. Jan Szczepański, like many others who love this land, strongly disagreed with the vision of the world as a supermarket with available cultural patterns (Mathews 2005). However, changes are inevitable. The penetration of cultures takes place not only between the border between Cieszyn and Czech Cieszyn, but also concerns the flows of culture that define the whole, largely globalized world. Cieszyn is one of the places that Kirsten Hastrup (2008, p. 160) wrote about, noting that 'we are all natives of some world. Despite the obvious globalization, there are still parts of the world where people are 'at home' - in the sense that the social space is known to them, even if they do not really understand it'.

\section{Connecting capital - support and co-presence}

The socio-cultural capital that is produced in Cieszyn and Czech Cieszyn is perceived in this paper in a perspective related to the works of Pierre Bourdieu $(1986,1994)$ and Robert Putnam $(1993$; $1995 ; 2000)$. The authors of the study realize, however, that the mentioned views are different. $\mathrm{P}$. Bourdieu emphasizes the play of interests over co-operability, which is the axis of R. Putnam's considerations. Analysing the situation that characterizes the cities described here, it can be noticed that in the social practice both of the recalled concepts can be current, as well as providing insight into the processes taking place in this field. For P. Bourdieu, socio-cultural capital is the total of real and potential resources associated with having a permanent network of more or less institutionalized relations of mutual knowledge and recognition - in other words, belonging to groups that provide each of its members with support of collectivity-owned capital, 'authentication' which entitles them to credit, in the broad spectrum of the meaning of the word. These relationships can only exist in a practical, material and/or symbolic exchange which helps them to maintain them (Bourdieu 1986, p. 249). Groups mentioned here are found on both sides of the Olza river. The structure of these groups 
is centred around various values, or in other words, around various shared factors. On the one hand, these are groups connected with running their businesses in the cities (frequent transfer of business from Poland to the Czech Republic due to legal transparency and tax conditions), on the other, numerous groups of associations, associations or organizations, focused on political or religious ideas (it must be remembered that Cieszyn is famous for its many religions). Among the indicated ones, speaking about socio-cultural capital, they perform mediating role as institutions related to local government, including educational and higher education institutions. It is worth mentioning here that on the Polish side there are two university colleges, i.e. the University of Silesia in Katowice and the WSB Academy in Dąbrowa Górnicza. For the development of socio-cultural capital, the activities of the University of Silesia (Faculty of Arts and the Faculty of Ethnology and Educational Sciences) are particularly important, which by educating future artists, cultural animators and teachers in a significant way marks its presence in the cultural offer of both cities. The scientific staff and students of both Cieszyn faculties of the University of Silesia are often originators and organizers of various types of cultural events (exhibitions, courses - for example, summer Polish language courses, concerts, festivals, etc.). Very often, it is people connected with this university who create new nongovernmental organizations operating in the field of culture. One might even be tempted to say that the city of Cieszyn is a kind of a 'training ground' where students of the Art Department or the Faculty of Ethnology and Education Sciences can gain their first experience as artists or culture animators. The activity of students in the area of culture undoubtedly generates a multitude of differently addressed offer, which is very often difficult to control - which is undoubtedly a big challenge for the Culture Department of the City of Cieszyn. The activities of the Branch Department in Cieszyn of the WSB Academy are not without significance. Despite the fact that it offers mainly technical and managerial studies in Cieszyn, it is also active in the field of culture. It can be illustrated by the research concerning the conditions for the functioning of the Polish-Czech cross-border cultural services market, conditions for the functioning of the Polish-Czech cultural cluster or such initiatives as: Cieszyn Children's University conducted in cooperation with the Culture Department in Cieszyn, Science Festival or regular scientific conferences devoted to contemporary management problems and marketing in cultural institutions. The activities of these two universities in Cieszyn are significantly reflected in the number of cultural entities operating on the Polish side (mainly nongovernmental organizations), as well as the available cultural offer (which thanks to these organizations is more rich and diverse).

The above-mentioned cooperation between local government institutions and the third sector, however, requires that the character of Cieszyn and Czesław Cieszyn should be closely related to the concept of social capital of R. Putnam. Putnam (1993, p. 177) emphasizes intra-social cooperation, a network of connections, a community of norms and trust. Social capital is funded here on social ties. The author of the book Bowling Alone (Putnam 2000) wrote: 'By 'social capital' I mean the characteristics of social life - networks, norms and trust - that enable participants to act more effectively in order to achieve common goals. Whether or not their common goals are commendable is, of course, a completely different matter. The extent to which standards, networks and trust connect significant sectors of the community and cover basic social divisions - the extent to which social capital is 'bridging'- enhanced cooperation can serve broader interests and it can be universally welcomed' (Putnam 1995, p. 664-665). Speaking of the same relations, P. Bourdieu (1994, p. 226) would point out the social framework within which field dynamics is concerned, as an area of struggle for hegemony, the position of its individual components. Cieszyn and Czech Cieszyn are not this kind of places, although in terms of efficiency, it is easy to point out those which to a greater extent than other entities imprint their mark on the image of both cities. The scale in this respect is extensive, from groups associated with local government authority, which has relatively the largest budget, numerous small organizations and a large number of 'critics' expressing expectations for activities in the field described, but without their direct involvement. This kind of situation, however, takes place in every major human population. Indeed, as far as the analysis of social and cultural life is concerned, it is difficult to see initiatives that would be institutionally subdued within this field (although non-granted ones can be found and thus suppressed). Activity in the area of socio-cultural capital production is not so much divisive as the consensus and the multiplicity of the addressed offer. Of course, the evaluation of what is happening is varied. However, there is one factor that favours community thinking, the same factor that simultaneously limits many actions to social and 
cultural capital - financial resources. This applies to both business and remuneration zone. Despite its importance, the culture sector is composed of staff who are not rewarded in a manner adequate to their qualifications. It is enough to mention that the average wage in houses and centres of cultures is often lower than the remuneration for work in other sectors (e.g. in retail trade or other ones that do not require a long education process). Basically, the entire sphere of culture in Poland and the Czech Republic can be considered underfunded. These kinds of problems are intensified by efforts to cooperate, to create social capital of a combining nature (as R. Putnam would say). What may be of particular interest here, in the light of research concerning the Polish environment of cultural workers, their low salary is not an obstacle to work, because 'passion and conviction about the high value of what you do, often against low wages, makes people decide to work in the cultural sector' (Dziadzia et al. 2015, p. 60). These ideological approach of cultural workers is often brutally exploited by principals, who assume that regardless of the remuneration, the tasks set for them will be done demonstrating a special kind of creativity.

\section{Conclusions}

The culture sector in Poland and the Czech Republic is a significant factor in the shaping of identity (Wróblewski 2012). At the same time, it adopts numerous organizational forms. In Poland, for example, it is present both at the national level (many activities are undertaken at the level of the Ministry of Culture and National Heritage together with subordinate institutions of a national nature) and it also has a significant role at the local government level. Each city, poviat or province office has its department for culture. The whole is complemented by bottom-up activities of the 3rd sector organization. Thus, it is possible to talk about multi-path creation of social cohesion framework (local, regional or national) and social and cultural capital, but also about shaping individual fates. The impact of the cultural sector is reflected in the identification and self-identification of groups and the entities that co-create them. As Stuart Hall noted, 'identification is based on the recognition of some common origin or common traits with another person or group, or with an ideal, and with the natural foundations of solidarity and loyalty established on this foundation. In contrast to the 'naturalism' of this definition, the discursive approach perceives identification as a construction, never-completed process - always 'in the process'. It is not defined in the sense that it can always be 'won' or 'lost', 'maintained or abandoned' (Hall 1996, p. 2). The process nature of identification shaping indicates the plasticity of socio-cultural capital. The analysis shows that it is determined, to varying degrees, by both socio-political and geographical location, the memory of the past, and the nature of the cultural offer - and this is always the result of the organizer's position, its potential, competence, and the ability to identify achievable goals. The example of the cities of Cieszyn and Czeski Cieszyn is no exception. The volatility of social and political relations, determines the current state of identification and identity as an open project, full of challenges that should be identified in terms of long duration (Braudel 1999, pp. 325-430). Hence the importance of NGOs' activities as well as the openness of the authorities to grassroot initiatives.

Author Contributions: Both authors contributed equally in the development of the present paper. For the proper paper developing, all the phases have been discussed and worked by the authors.

Conflicts of Interest: The authors declare no conflict of interest.

\section{References}

1. Anderson, Benedict. 2006. Imagined Communities. Reflections on the Origin and Spread of Nationalism; Revised Edition. London-New York: Verso. ISBN 978-1-84467-086-4

2. Appadurai, Arjun. 1996. Modernity at Large. Cultural Dimensions of Globalization. Minneapolis: University of Minnesota Press. ISBN 081-6-627-924 
3. Bourdieu, Pierre. 1994. Distinction. A Social Critique of the Judgement of Taste. Cambridge: Harvard University Press. ISBN 0-674-21277-0

4. Bourdieu, Pierre. 1986. The Forms of Capital. In: Handbook of Theory and Research for the Sociology of Education. Edited by Jon Richardson. New York: Westport, CT.

5. Braudel, Fernand. 1999. Historia i trwanie. Warsaw: Czytelnik. ISBN 830-7-027-128

6. Castanho, Rui Alexandro, Loures Luis, Cabezas Jose, and Fernández-Pozo Luis. 2017. Cross-Border Cooperation (CBC) in Southern Europe-An Iberian Case Study. The Eurocity Elvas-Badajoz. Sustainability 9, 360. DOI: 10.3390/su9030360

7. Dziadzia, Bogusław, Konieczna Ewelina, Liniany Jan, Skutnik Jolanta, and Sieroń-Galusek Dorota. 2015. Podnoszenie kompetencji kadr kultury w domach, centrach i ośrodkach kultury. Katowice: Regionalne Obserwatorium Kultury. ISBN: 978-83-930479-7-0

8. Dziadzia, Bogusław. 2014. Naznaczeni popkultura. Media elektroniczne i przemiany prowincji. Gdańsk: Wydawnictwo Naukowe Katedra. ISBN: 978-83-63434-24-3

9. Global Index of Religiosity and Atheism. WIN-Gallup International. Available online: https://sidmennt.is/wp-content/uploads/Gallup-International-um-tr\%C3\%BA-og-tr\%C3\%BAleysi2012.pdf (accessed on 31 August 2018).

10. Hall, Stuart. 1996. Introduction: Who Needs 'Identity'? In Questions of Cultural Identity. Edited by Stuart Hall, Paul du Gay. London- Thousand Oaks-New Delhi: Sage Publications. ISBN 0-8039-7883-9

11. Hastrup, Kirsten. 2008. Droga do antropologii. Między doświadczeniem a teoria. Cracow: Wydawnictwo Uniwersytetu Jagiellońskiego. ISBN: 978-83-223-2449-2

12. Kurowska-Pysz, Joanna. 2015. Assessment of trends for the development of cross border cultural clusters. Forum Scientiae Oeconomia 3: 31-51.

13. Kurowska-Pysz, Joanna, Wróblewski Łukasz, and Szczepańska-Woszczyna Katarzyna. 2017. Identification and assessment of barriers to the development of cross-border cooperation. In Innovation Management and Education Excellence through Vision 2020. Edited by Khalid Soliman. Milano: Proceedings of the 31st International Business Information Management Association Conference. ISBN: 978-0-9998551-0-2

14. Kurowska-Pysz, Joanna. 2016. Opportunities for Cross-Border Entrepreneurship Development in a Cluster Model Exemplified by the Polish-Czech Border Region. Sustainability 8, 230. DOI:10.3390/su8030230

15. Kurowska-Pysz, Joanna, Castanho Rui Alexandro, and Naranjo Gómez Jose Manuel. 2018. Crossborder cooperation-The barriers analysis and the recommendations. Polish Journal of Management Studies 17: 134-147. DOI: 10.17512/pjms.2018.17.2.12

16. Mathews, Gordon. 2005. Supermarket kultury. Warsaw: Państwowy Instytut Wydawniczy.

17. Putnam, Robert. 2000. Bowling Alone: The Collapse and Revival of American Community. New York: Simon \& Schuster Paperbacks. ISBN 978-0743203043

18. Putnam, Robert. 1993. Making Democracy Work Civic Traditions In Modern Italy, Princeton: Princeton University Press. ISBN 0-691-07889-01

19. Putnam, Robert. 1995. Turning in, turning out: the strange disappearance of social capital in America. Political Science and Politics 28, 4 .

20. Schwab, Klaus. 2016. The Global Competitiveness Report 2016-2017. Geneva: World Economic Forum. ISBN 978-1-944835-04-0

21. Stosunek Polaków do innych narodów. 2013. Warsaw: Centrum Badania Opinii Społecznej Available online: https://www.cbos.pl/SPISKOM.POL/2013/K_012_13.PDF (accessed on 31 August 2018). 
22. Szczepański, Jan. 2013. Korzeniami wrosłem w ziemię, Ustroń: Galeria „Na Gojach”. ISBN 978-83-6055145-5

23. Weil, Simone. 2002. The Need for Roots: prelude towards a declaration of duties towards mankind. LondonNew York: Routledge. ISBN 978-04-152-7101-1

24. Wróblewski, Łukasz. 2012. Strategie marketingowe w instytucjach kultury. Warsaw: PWE. ISBN 978-83208-1982-3.

25. Wróblewski, Łukasz. 2014. The Influence of Creative Industries on the Socioeconomic Development of Regions in Poland. International Journal of Entrepreneurial Knowledge 2: 45-57.

26. Wróblewski, Łukasz. 2015. Websites of Polish cultural and educational organizations in the Czech Republic-Analysis and evaluation. Forum Scientiae Oeconomia 3: 65-78.

27. Wróblewski, Łukasz. 2016. Marketing strategiczny w sektorze kultury Euroregionu Ślask Cieszyński. Warsaw: CeDeWu. ISBN 978-83-7556-845-5.

28. Wróblewski, Łukasz. 2017b. Application of marketing in cultural organizations: the case of the Polish Cultural and Educational Union in the Czech Republic. Cultural Management Science and Education 1: 79-92.

29. Wróblewski, Łukasz. 2017a. Cultural Management. Strategy and Marketing Aspects. Berlin: Logos Verlag Berlin. ISBN 978-3-8325-4378-5.

30. Wróblewski, Łukasz, Kurowska-Pysz Joanna, and Zdzisława Dacko-Pkiewicz. 2018. Polish-Czech micro-projects as a tool for shaping consumer behaviour on the cross-border market for cultural services. In: Innovation Management and Education Excellence through Vision 2020. Edited by Khalid Soliman. Milano: Proceedings of the 31st International Business Information Management Association Conference. ISBN: 978-0-9998551-0-2

31. Wróblewski, Łukasz, Dziadzia Bogusław, and Zdzisłąwa Dacko-Pikiewicz. 2018. Sustainable Management of the Offer of Cultural Institutions in the Cross-Border Market for Cultural ServicesBarriers and Conditions. Sustainability 10, 9. DOI:10.3390/su10093253.

32. Vztah ceské verejnosti $k$ národnostním skupinám zijícím v CR. 2015. Centrum pro výzkum veřejného mínění. Sociologický ústav AV CR. Prague. Available online: https://cvvm.soc.cas.cz/media/ com_form2content/documents/c2/a1868/f9/ov150306.pdf (accessed on 31 August 2018). 